\title{
Insulin binding to trophoblast plasma membranes and placental glycogen content in well-controlled gestational diabetic women treated with diet or insulin, in well-controlled overt diabetic patients and in healthy control subjects
}

\author{
G. Desoye, H. H.Hofmann and P. A.M. Weiss \\ Department of Obstetrics and Gynecology, University of Graz, Graz, Austria
}

\begin{abstract}
Summary. Insulin binding to trophoblast plasma membranes and the placental glycogen content were measured in twelve healthy women, in eleven well-controlled gestational diabetic women who were treated either with diet alone $(n=4)$ or with insulin $(n=7)$ and in 18 women with well-controlled overt diabetes mellitus (six White B; four White C; eight White D). The competitive binding assay was carried out with 22 concentrations of unlabelled insulin. Binding data were analysed by a non-linear direct model fitting procedure assuming one non-cooperative binding site. Maximum specific binding was unchanged in the total collective of gestational diabetic women, but was decreased by $30 \%$ in those treated with diet $(6.2 \pm 2.2 \%)$ and increased by $90 \%$ in insulin-treated women $(16.4 \pm 10.2 \%)$ as compared to the control subjects $(8.7 \pm 2.5 \%)$. The diet-treated women had only $40 \%$ as many and those treated with insulin had more than twice as many receptors compared to control subjects on a per $\mathrm{mg}$ protein basis and if expressed per total placenta. In patients with overt diabetes mellitus maximum specific binding $(18.5 \pm 10.6 \%)$ was higher $(p<0.05)$ due to more receptors compared to control subjects but was similar to the insulin-treated gestational diabetic patients. Maximum specific binding and receptor concentrations did not correlate line-
\end{abstract}

arly with maternal plasma insulin levels. Receptor affinities were virtually similar in all groups $\left(1.8 \cdot 10^{9} 1 / \mathrm{mol}\right)$. The placental glycogen content was reduced $(p<0.05)$ to about $80 \%$ of that of control subjects in the diet-treated collective, whereas it was unchanged compared to control subjects in the insulin-treated gestational diabetic women despite a $40 \%$ increase $(p<0.001)$ of the maternal-to-cord serum glucose ratio. In overt diabetic patients the maternal-to-cord serum glucose ratio and the placental glycogen content were higher $(p<0.05)$ than in the control subjects. We conclude that trophoblast plasma membranes from gestational diabetic women treated with diet alone express less and those from women treated with insulin express more insulin receptors than those from a healthy control group in vitro. These differences could not have been disclosed without consideration of the mode of treatment. Trophoblast plasma membranes from overt diabetic women have more insulin receptors than those from healthy control subjects.

Key words: Insulin binding, insulin receptors, glycogen, trophoblast, placenta, gestational diabetes, overt diabetes mellitus, diabetes and pregnancy.
Gestational diabetes is a transient intolerance of carbohydrates during human pregnancy which becomes detectable by oral glucose tolerance testing between the 20th and 28th gestational weeks [1]. Inadequate treatment of maternal hyperglycaemia leads to fetal hyperinsulinism with ensuing macrosomia and increased perinatal morbidity [2]. Infants born of pregnancies complicated by gestational diabetes may have an increased risk of obesity and diabetes later in life by a process called fuel-mediated teratogenesis [3]. A large proportion of women with gestational diabetes eventually develop overt diabetes over the next few years [4].

The aetiology of gestational diabetes is still not fully understood. Genotypic differences between metabo- lically normal and gestational diabetic mothers have been demonstrated [5]. Insulin resistance has been suggested to contribute substantially to the deterioration of glucose homeostasis [5, 6]. It is now widely accepted that tissue insulin resistance is associated with a decreased number of insulin receptors, reduced activity of the receptor-intrinsic tyrosine kinase, or both.

The human placenta contains a large number of insulin receptors [7] located on the microvillous membrane of the syncytiotrophoblast $[8,9]$. In pregnancies complicated by gestational [10] or overt diabetes mellitus [11] the human placenta shows a variety of structural and metabolic alterations. Since the placental insulin receptors are in intimate contact with the maternal circulation, it can be assumed 
Table 1. Characteristics of metabolically normal women (control subjects), well-controlled gestational diabetic women and women with wellcontrolled overt diabetes mellitus (ODM) and of their offsprings

\begin{tabular}{|c|c|c|c|c|c|}
\hline \multirow[t]{2}{*}{ Parameters } & \multirow[t]{2}{*}{ Control subjects } & \multicolumn{3}{|c|}{ Gestational diabetes } & \multirow[t]{2}{*}{ ODM } \\
\hline & & Diet treated & Insulin treated & Total & \\
\hline$n$ & 12 & 4 & 7 & 11 & 18 \\
\hline Length of gestation (weeks) & $39.7 \pm 1.6$ & $39.8 \pm 2.3$ & $38.6 \pm 1.7$ & $39.1 \pm 1.9$ & $37.5 \pm 2.4^{\mathrm{d}}$ \\
\hline Age (years) & $26.5 \pm 5.4$ & $25.4 \pm 6.7$ & $29.6 \pm 4.0$ & $28.0 \pm 5.4$ & $27.8 \pm 5.3$ \\
\hline Height $(\mathrm{cm})$ & $164 \pm 6$ & $163 \pm 10$ & $161 \pm 6$ & $162 \pm 10$ & $165 \pm 4$ \\
\hline $\mathrm{BMI}^{\mathrm{a}}$ & $23.9 \pm 5.9$ & $23.0 \pm 3.9$ & $24.7 \pm 6.2$ & $24.0 \pm 5.3$ & $24.2 \pm 3.1$ \\
\hline Weight gain (kg) & $12.6 \pm 3.9$ & $12.1 \pm 7.1$ & $11.2 \pm 3.3$ & $11.6 \pm 4.8$ & $14.6 \pm 4.9$ \\
\hline Birth weight (g) & $3390 \pm 465$ & $3372 \pm 437$ & $2949 \pm 508$ & $3112 \pm 510$ & $2972 \pm 702$ \\
\hline Birth height $(\mathrm{cm})$ & $50 \pm 3$ & $50 \pm 1$ & $49 \pm 2$ & $49 \pm 2$ & $50 \pm 3$ \\
\hline Placental weight $(\mathrm{g})$ & $594 \pm 91$ & $602 \pm 22$ & $525 \pm 69^{b, c}$ & $555 \pm 67$ & $671 \pm 278$ \\
\hline
\end{tabular}

${ }^{a}$ Body mass index (BMI) calculated as weight $(\mathrm{kg}) /$ height $^{2}(\mathrm{~m}) ;{ }^{\mathrm{b}} p<0.05$ vs diet-treated group; ${ }^{\mathrm{c}} p<0.05 ;{ }^{\mathrm{d}} p<0.01 \mathrm{vs}$ control group. Mean \pm SD

that abnormalities of maternal carbohydrate and insulin metabolism affect placental insulin receptors. Their status in gestational diabetes is only scantly documented [12]. The influence of overt diabetes on the placental insulin receptors has been investigated several times producing conflicting results [13-17].

The present study analysed insulin binding to placental membranes from metabolically normal mothers and wellcontrolled gestational diabetic women (GD), who had been treated either with diet alone (DGD) or with diet and insulin (IGD). Moreover, women with well-controlled overt insulin-dependent diabetes (ODM) were included in the study. In addition the placental content of glycogen was measured, because no data have been reported so far on the placental glycogen content in GD and in subclasses of ODM and because, although still highly controversial, insulin might affect the glycogen content and the activity of the relevant placental enzymes [18-21].

\section{Subjects, materials and methods}

\section{Control subjects}

The control group comprised 12 women randomly chosen from the outpatient obstetric care unit of the Department of Obstetrics and Gynecology (Table 1). These women met the following criteria: normal oral glucose tolerance test (OGTT) results between weeks 20 and 28; normal course and outcome of singleton pregnancy; no endocrine abnormalities; no family history of diabetes; no hypertension at the end of pregnancy; term delivery; no smoking during pregnancy; customary diet; no systematic attempt to restrict calories; and no medication except multivitamins and iron supplementation. The control subjects represent average Austrian pregnant women (Table 1).

\section{Gestational diabetic women}

Pregnant women were considered to be gestational diabetic if one value of a routine OGTT exceeded $8.9 \mathrm{mmol} / 1$ [1], $99.3 \%$ of the elevated levels occurred after $1 \mathrm{~h}$. Compliance with overnight fasting was questioned in patients with only an elevated fasting glucose level
(>6.1 $\mathrm{mmol} / \mathrm{l}$ ) and the OGTT was repeated. Women with a positive OGTT were treated with a diet of $30-35 \mathrm{kcal} / \mathrm{kg}$ ideal weight [(body height in $\mathrm{cm}-100) \times 0.9)]$.

Fasting glucose levels were measured weekly. The amniotic fluid insulin levels (AFI) were measured between weeks 28 and 32. Subsequently, women with an AFI below $10 \mu \mathrm{U} / \mathrm{ml}($ mean $+3 \mathrm{SD})$ continued to be treated with diet alone (diet-treated group; DGD). The diet comprised five meals per day and was high in protein and carbohydrates and low in fats. Women with an AFI level exceeding $10 \mu \mathrm{U} / \mathrm{ml}$ were additionally treated with insulin (insulin-treated group; IGD). Insulin was administered following a basal-bolus protocol [22]; the average daily insulin requirement was 70 IU. No glucose administration during delivery was necessary. The women showed normal carbohydrate tolerance in a post-partum follow-up, indicating that they had Type 2 (non-insulin-dependent) diabetes.

\section{Overtly diabetic women}

Eighteen Type 1 (insulin-dependent) diabetic pregnant women were studied. Demographic and clinical data of the patients are presented in Table 1. Diabetes was classified according to White [23]. An $\mathrm{R}$ was appended to the White class in patients with background retinopathy [24]. Most patients were first seen in the Diabetes Unit of our department between gestational weeks 8 and 12 , when they were entered into the study. Treatment aimed to achieve fasting serum glucose levels $<6.1 \mathrm{mmol} / 1$, postprandial serum glucose levels $<8.5 \mathrm{mmol} / \mathrm{l}$ and a mean serum glucose concentration $<6.1 \mathrm{mmol} / \mathrm{l}$. Metabolic control was carried out in the hospital for instituting therapy and continued mainly on an outpatient basis [25]. Human insulin was administered in four daily doses following a basal-bolus protocol [22]. The total daily insulin requirement at term averaged 90 IU. Details of therapy and monitoring procedures during pregnancy have been described elsewhere $[22,25]$. None of the patients received glucose during delivery.

\section{Materials}

Monoiodinated (A14Tyr)-[ $\left[{ }^{125} \mathrm{I}\right]$-insulin (specific activity approximately $2000 \mathrm{Ci} / \mathrm{mmol}$ ) and $\left[{ }^{3} \mathrm{H}\right]$-inulin (specific activity $1 \mathrm{Ci} / \mathrm{mmol}$ ) were obtained from Amersham (Little Chelfond, UK), human monocomponent insulin from Novo (Vienna, Austria), Aspergillus niger amyloglucosidase (EC 3.2.1.3) from Boehringer Mannheim (Mannheim, FRG), and neuraminidase (EC 3.2.1.18) from vibrio cholerae from Behringwerke (Marburg, FRG). All other enzymes, 
Table 2. Parameters of carbohydrate metabolism in 12 metabolically normal women (control subjects), 11 well-controlled gestational diabetic patients and 18 women with well-controlled overt diabetes mellitus (ODM)

\begin{tabular}{|c|c|c|c|c|c|}
\hline \multirow[t]{2}{*}{ Parameters } & \multirow{2}{*}{$\begin{array}{l}\text { Control } \\
\text { subjects }\end{array}$} & \multicolumn{3}{|c|}{ Gestational diabetes } & \multirow[t]{2}{*}{ ODM } \\
\hline & & Diet treated & Insulin treated & Total & \\
\hline $\begin{array}{l}\text { Fasting serum } \\
\text { insulin }(\mu \mathrm{U} / \mathrm{ml})^{\mathrm{a}}\end{array}$ & $\begin{array}{l}14 \pm 3 \\
(13)\end{array}$ & $\begin{array}{l}13 \pm 11 \\
(11)\end{array}$ & $\begin{array}{l}31 \pm 28^{c} \\
(21)\end{array}$ & $\begin{array}{l}24 \pm 24 \\
(20)\end{array}$ & $\begin{array}{l}42 \pm 68 \\
(26)\end{array}$ \\
\hline $\begin{array}{l}\text { Fasting blood } \\
\text { glucose }(\mathrm{mg} / 100 \mathrm{ml})^{\mathrm{a}}\end{array}$ & $\begin{array}{l}71 \pm 7 \\
(76)\end{array}$ & $\begin{array}{l}83 \pm 15 \\
(82)\end{array}$ & $\begin{array}{l}96 \pm 28 \\
(96)\end{array}$ & $\begin{array}{l}91 \pm 24 \\
(82)\end{array}$ & $\begin{array}{l}102 \pm 84 \\
(91)\end{array}$ \\
\hline $\begin{array}{l}\text { Cord serum } \\
\text { insulin }(\mu \mathrm{U} / \mathrm{ml})\end{array}$ & $\begin{array}{l}9 \pm 4 \\
(8)\end{array}$ & $\begin{array}{l}9 \pm 5 \\
(7)\end{array}$ & $\begin{array}{l}9 \pm 4 \\
(8)\end{array}$ & $\begin{array}{l}9 \pm 4 \\
(8)\end{array}$ & $\begin{array}{l}37 \pm 40 \\
(22)\end{array}$ \\
\hline $\begin{array}{l}\text { Amniotic fluid glucose } \\
\text { at delivery }(\mathrm{mg} / 100 \mathrm{ml})\end{array}$ & $\begin{array}{l}16 \pm 7 \\
(16)\end{array}$ & $\begin{array}{l}16 \pm 5 \\
(14)\end{array}$ & $\begin{array}{l}35 \pm 30 \\
(28)\end{array}$ & $\begin{array}{l}28 \pm 26 \\
(16)\end{array}$ & $\begin{array}{l}39 \pm 29 \\
(27)\end{array}$ \\
\hline $\mathrm{HbA}_{1 \mathrm{c}}(\%)$ & $\begin{array}{l}3.3 \pm 0.3 \\
(3.4) \\
\end{array}$ & $\begin{array}{l}3.6 \pm 0.4 \\
(3.7) \\
\end{array}$ & $\begin{array}{l}4.2 \pm 0.8 \\
(4.5)\end{array}$ & $\begin{array}{l}4.0 \pm 0.7 \\
(3.8)\end{array}$ & $\begin{array}{l}5.2 \pm 1.1 \\
(4.9)\end{array}$ \\
\hline
\end{tabular}

${ }^{\mathrm{a}}$ measured in the last week before delivery; ${ }^{\mathrm{b}} p<0.01 \mathrm{vs}$ diet-treated group; ${ }^{\mathrm{c}} p<0.05$ vs control group. Mean $\pm \mathrm{SD}$ (median)

substrates and bovine serum albumin (BSA) were from Sigma Chemie (Taufkirchen, FRG); all solvents were from Merck (Darmstadt, FRG), at the highest available purity.

\section{Blood and plasma analysis}

Total plasma insulin was measured using a commercially available radioimmunoassay (RIA) kit (Phadebas, Pharmacia, Uppsala, Sweden) following the protocols given by the manufacturer. If necessary to measure within the linear range of the calibration curve, plasma was diluted with $0.9 \% \mathrm{NaCl}$ solution. The cross-reactivity of the anti-insulin antibody with C-peptide is less than $0.2 \%$. The intraassay coefficient of variation was less than $2.3 \%$; the inter-assay coefficient of variation was less than $6 \%$. Plasma and amniotic fluid glucose values were determined by the glucose oxidase method (Beckman glucose analyser, Beckman Instruments, Fullerton, Calif., USA).

The OGTT was performed between weeks 20 to 28 of gestation after 3 days of a normal diet and after overnight fasting. Loading was performed in the morning with $1 \mathrm{~g}$ of glucose per kilogram body weight [26]. Capillary blood glucose was measured in the fasting state and 1 and $2 \mathrm{~h}$ after glucose ingestion with a commercially-available kit (Gluco-quant, Boehringer Mannheim), based on the hexokinase method. Glycosylated haemoglobin $\left(\mathrm{HbA}_{1 \mathrm{c}}\right)$ was measured by a commercially-available minicolumn test (Bio-Rad Laboratories, Hercules, Calif., USA) with an intra-assay coefficient of variation less than $2 \%$ and an inter-assay coefficient of variation less than $4 \%$. The $95 \%$ confidence limits for metabolically normal pregnant women are $3.4 \%$ and $5.5 \%[27]$.

The concentrations of anti-insulin antibodies in serum were measured by a commercially available ELISA-kit (Elias, Freiburg, FRG) with a normal range of $0-5 \mathrm{U} / \mathrm{ml}$. Units are defined on a linear scale. A 1:400 dilution of an IgG fraction of a severely diabetic patient gave maximal absorption in the assay design and was arbitrarily set to 100 units (information from the manufacturer of the kit). In IGD and in ODM the concentrations of insulin antibodies were similar to DGD and to control subjects and never exceeded $5 \mathrm{U} / \mathrm{mI}$ in maternal serum (data not shown). Their concentrations in cord serum were below the sensitivity of the assay $(<1 \mathrm{U} / \mathrm{ml})$. Parameters of carbohydrate metabolism are summarized in Table 2 .

\section{Preparation of tissue and plasma membranes}

Placentae were collected on ice immediately after delivery, dissected from amnion and chorion, and washed free of blood in $50 \mathrm{mmol} / 1$ Tris/ $\mathrm{HCl}$ ( $\mathrm{pH} 7.4$ ). About 60-80 g of tissue were dissected from the centre of cotyledons, cut into pieces of about $3 \mathrm{~cm}$, and washed again. For the determination of glycogen, approximately 1-g pieces were cut from the centre of cotyledons and snap frozen at 5 -min intervals until $60 \mathrm{~min}$ after delivery and stored in liquid nitrogen.

In pilot experiments, placental plasma membranes were prepared following two different protocols $[28,29]$. Although the binding levels were comparable, the reproducibility of the binding data proved better with membranes prepared according to Haour's protocol [29], which was therefore used in this study. Briefly, the tissue was cut into small pieces, washed again, and then ground in a glass homogenizer containing $50 \mathrm{mmol} / \mathrm{l}$ Tris/ $\mathrm{HCl}(\mathrm{pH} 7.4)$ and $0.25 \mathrm{~mol} / \mathrm{l}$ sucrose (preparation buffer). About $2 \mathrm{ml}$ of homogenate were removed and stored at $-40^{\circ} \mathrm{C}$ for further analysis. The remaining homogenate was centrifuged at $600 \times g$ for $10 \mathrm{~min}$. The supernatant, which was free of nuclei and cellular debris, was centrifuged again at $10,000 \times g$ for $10 \mathrm{~min}$ and the pellet washed and centrifuged in preparation buffer at $20,000 \times g$ for $20 \mathrm{~min}$. The pellet was washed once in Tris-buffer without sucrose and suspended in $20 \mathrm{ml}$ of Tris-buffer. All steps were carried out at $4^{\circ} \mathrm{C}$.

Measurement of protein content was made with $500 \mu \mathrm{l}$ of membrane suspension [30] using BSA as the standard. The suspension was diluted to a final concentration of approximately $1 \mathrm{mg}$ protein/ml.

\section{Insulin receptor analysis}

The measurement of insulin binding has been described elsewhere [7]. Briefly, placental plasma membranes (approximately $0.2 \mathrm{mg}$ protein/tube) were incubated with monoiodinated insulin (approximately $70,000 \mathrm{cpm})$ in $50 \mathrm{mmol} / 1 \mathrm{Tris} / \mathrm{HCl}(\mathrm{pH} 7.4)$ at $4{ }^{\circ} \mathrm{C}$ in the presence of 22 increasing concentrations of unlabelled insulin, ranging from $1.65 \mathrm{pmol} / \mathrm{l}$ to $49.5 \mathrm{nmol} / 1$. Nine parallel incubations were performed for each of 13 different concentrations of insulin between $1.65 \mathrm{pmol} / \mathrm{l}$ and $660 \mathrm{pmol} / \mathrm{l}$ because measurements at these low concentrations are very sensitive to experimental errors (intra-assay coefficient of variation $<13 \%$ ). The remaining 9 concentrations between $1.65 \mathrm{nmol} / \mathrm{l}$ and $49.5 \mathrm{nmol} / \mathrm{l}$ were run in triplicate (intra-assay coefficient of variation $<7 \%$ ). The total assay volume was $0.5 \mathrm{ml}$. After $20 \mathrm{~h}$, the membrane suspensions were diluted with pre-cooled buffer and centrifuged at $4000 \times g$ for $45 \mathrm{~min}$. Pilot experiments had demonstrated that steady-state was reached after $16 \mathrm{~h}$. The supernatant containing unbound insulin was discarded. Non-specific binding was measured in 6 parallel incubations at both $4.95 \mu \mathrm{mol} / \mathrm{l}$ and $49.5 \mu \mathrm{mol} / 1$ unlabelled insulin concentrations. Each analysis thus comprised a total of 156 assay tubes. Radioactive disintegrations of bound tracer were counted in a calibrated 16-channel counter (Nuclear Enterprises NE 1600; variations between channels $<1 \%$ ) at approximately $65 \%$ counting efficiency. Tracer purity and degrada- 
Table 3. Characterization of crude homogenates and membrane suspensions prepared from placentae of 12 metabolically normal women, 11 well-controlled gestational diabetic patients and 18 women with well-controlled overt diabetes mellitus of different White classes

\begin{tabular}{lccc}
\hline & Crude homogenate & Membrane suspension & Enrichment $(\%)$ \\
\hline Protein (mg/g placenta) & $74.3 \pm 11.7$ & $2.14 \pm 0.73$ & $2.9 \pm 1.0$ \\
Sialic acids (nmol/mg prot) & $16.0 \pm 5.0$ & $31.7 \pm 9.7$ & $219 \pm 98$ \\
5'-nucleotidase (mU/mg prot) & $19.5 \pm 8.4$ & $168.1 \pm 68.7$ & $832 \pm 301$ \\
Alkaline phosphatase (mU/mg prot) & $82.7 \pm 38.9$ & $1211 \pm 320$ & $1386 \pm 724$ \\
Beta-glucuronidase (U/mg prot) & $66.3 \pm 35.2$ & $24.1 \pm 9.5$ & $35.6 \pm 16.2$ \\
Isocitrate-dehydrogenase (mU/mg prot) & $16.5 \pm 10.8$ & $6.5 \pm 7.0$ & $39.2 \pm 40.6$ \\
\hline
\end{tabular}

Enrichment (\%) expresses the amount of the different components in the final membrane suspension relative to crude homogenate (100\%). Mean \pm SD

tion, as measured by precipitation with $20 \%$ (final concentration) trichlor-acetic acid, were higher than $97 \%$ and below $2 \%$, respectively. Tracer degradation was not affected by GD or ODM or by addition of bacitracin $(2 \%)$ or phenylmethyl-sulphonylfluoride $(1 \mathrm{mmol} / \mathrm{l})$ to the assay buffer. The amount of trapped radioactivity in the pellet was measured with $\left[{ }^{3} \mathrm{H}\right]$-inulin and was less than $0.2 \%$ of total activity.

\section{Enzymes and sialic acids}

By measuring the liberation of adenosine from AMP 5'-nucleo tidase (EC 3.1.3.5) was determined [31]. Alkaline phosphatase (EC 3.1.3.1) was measured according to Bowers and McCombe [32], beta-glucuronidase (EC 3.2.1.31) by the method of Fishman et al. [33] with the modification of a $1-h$ incubation at $56^{\circ} \mathrm{C}$, and isocitratedehydrogenase (EC 1.1.1.42) according to Bowers [34]. Sialic acids were analysed by the thiobarbituric acid method of Warren [35].

\section{Measurement of placental glycogen}

The frozen placental pieces were homogenized in $0.6 \mathrm{~mol} / \mathrm{l}$ perchloric acid at $4^{\circ} \mathrm{C}$ for $60 \mathrm{~s}$. Immediately thereafter the homogenate was neutralized with $1 \mathrm{~mol} / 1 \mathrm{KHCO}_{3}$, glycogen was degraded with amyloglucosidase (EC 3.2.1.3) for $2 \mathrm{~h}$ at $40^{\circ} \mathrm{C}$ and the released glucose measured by the hexokinase method. Basal tissue glucose levels were measured by replacing amyloglucosidase by buffer (acetate $0.2 \mathrm{~mol} / \mathrm{l}, \mathrm{pH} 4.8$ ). Tissue glycogen was calculated as the difference between total tissue glucose after glycogen degradation and basal tissue glucose and expressed in $\mu \mathrm{g}$ glycosylic residues/g placental wet weight.

\section{Data reduction and calculations}

Insulin binding was analysed by fitting the data in terms of the actual measured quantity (cpm) according to non-cooperative models comprising either one class of binding sites or two classes of inde pendent, non-interacting binding sites. Both models were analyti cally formulated by non-linear regression functions derived from the laws of mass action and mass conservation $[7,36]$ describing the dependent, observed variable (expressed in cpm) as a function of the independent variable (concentrations of unlabelled insulin). Therefore, the raw data of the individual competition curves were fitted without any transformation. In the computerized fitting procedure, pre-estimates of parameters were entered into the regression functions and the sums of squared residuals were minimized by iteratively adjusting parameter estimates by a Gauss-Newton algorithm with improvement for convergence of Levenberg-Marquart [37]. Nonspecific binding was not included as parameter in the fitting procedure because it was reliably measured in the experiments and be- cause the number of parameters for the fitting procedure should be kept as low as possible (low degrees of freedom).

The concentration of the receptor-insulin complex was calculated from the determined values of receptor concentrations and affinities and the corresponding individual ambient serum insulin concentrations assuming a one-to-one complex [38]. Receptor occupancy was expressed as the fraction of receptors occupied by insulin and calculated from the concentrations of receptor-insulincomplex and total receptors.

\section{Model selection}

The most appropriate model was selected by visual inspection of residual plots, by comparison of the residual variances of the fits using a partial F-test [39], and by calculating the Akaike Information Criterion (AIC) [40] in the modification of Lipkin [41]. The AIC is a number which, when lowest for a given data set, indicates the statistically-preferred model.

\section{Statistical analysis}

The non-parametric Wilcoxon rank sum test was used for intergroup comparisons. Significances were accepted at the level of $95 \%$ or more. Linear correlations between variables were tested by calculating Pearson's correlation coefficient.

\section{Results}

The membranes prepared from 60 to $80 \mathrm{~g}$ of wet tissue contained about 130 to $180 \mathrm{mg}$ of membrane protein with a relative amount of $2.1 \mathrm{mg}$ protein per g placental tissue. This amounts to a protein yield of about $3 \%$ of the initial material (Table 3 ). The relative content of sialic acids was about two times higher in the membrane preparation than in the crude placental homogenate. Activities of 5'-nucleotidase and alkaline phosphatase, located in the plasma membranes, were considerably increased, whereas the activities of beta-glucuronidase, which is considered lysosome-specific, and of isocitrate-dehydrogenase, a marker of mitochondrial membranes, were reduced to about $37 \%$ of initial activity. No differences were observed between the control group and both groups of diabetic women (data not shown). Therefore, the results from all groups were pooled for the presentation of membrane characteristics (Table 3).

A critical step determining the reproducibility of binding data was the resuspension of pelleted membranes after 

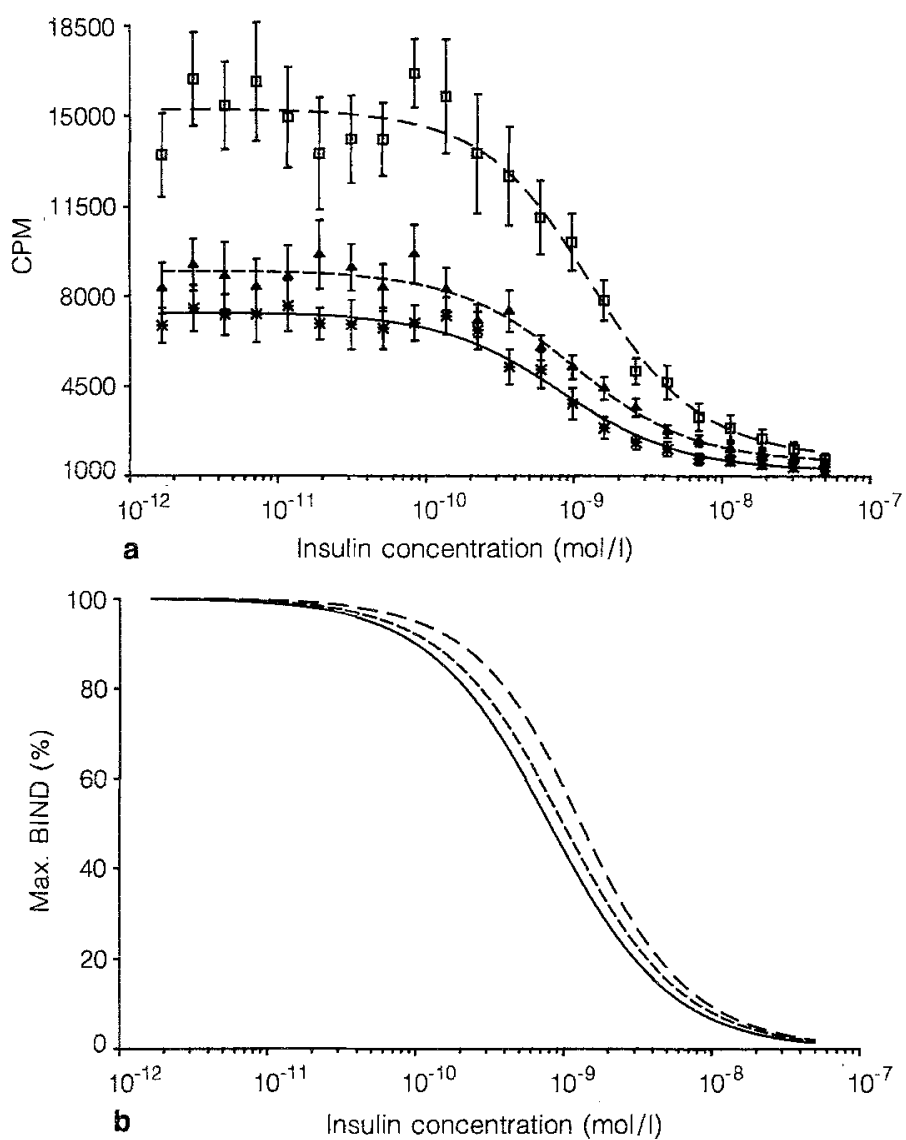

Fig.1a,b. Competition experiments with ${ }^{125} \mathrm{I}$-insulin and unlabelled insulin on trophoblast membranes from placentae of 12 healthy pregnant (*-*), 11 gestational diabetic (4--) women and 18 women with overt diabetes mellitus. ( $\square---\square)$. The lines represent the best fit of the data by the non-linear regression procedure. a Mean binding curve. Individual binding data normalized for $200 \mu \mathrm{g}$ protein per assay tube, and the mean $( \pm \mathrm{SD}) \mathrm{cpm}$ value calculated for each concentration of unlabelled insulin. b Competition profile

the final washing step, which might have caused an inconsistent degree of homogeneity because of membrane aggregation. Sonification of the suspensions for about $10 \mathrm{~s}$ during careful cooling at $4^{\circ} \mathrm{C}$ with a precooled microtip on a sonifier ( $40 \mathrm{~W}$ energy setting; Labsonic, Braun, Melsungen, FRG) reduced the variations without affecting the degree of specific binding (data not shown), which began to decline after $30 \mathrm{~s}$ of sonification. This is similar to results obtained with placental homogenates [42].

The purity of ${ }^{125} \mathrm{I}$-insulin was always greater than $97 \%$. Further purification on diethylaminoethyl (DEAE) cellulose [43] did not improve the reproducibility of data and did not affect the binding values (mean \pm SD of three independent experiments: $9.6 \pm 1.9 \%$ without vs $9.7 \pm 1.8 \%$ of total activity with further purification). Therefore, the tracer was used without additional purification.

Membrane preparation was begun immediately after delivery because storage of the placentae on ice decreased insulin binding after about 60 to $90 \mathrm{~min}$. In three independent experiments, the mean percentage of maximum total binding dropped from $9.4 \%$ after immediate placental processing to $9.1 \%, 9.0 \%$ and $8.5 \%$ after processing at
$60 \mathrm{~min}, 90 \mathrm{~min}$ and $120 \mathrm{~min}$, respectively. Binding levels were unaltered for about 7 days in one set of membranes prepared and kept frozen at $-4^{\circ} \mathrm{C}$ (data not shown).

Maximum specific binding of ${ }^{125} \mathrm{I}$-insulin was a linear function of plasma membrane protein concentration in the assay over a range from $50 \mu \mathrm{g}$ /assay tube to $700 \mu \mathrm{g} /$ assay tube $(r=0.95)$. Therefore, insulin binding was measured with protein concentrations in the linear range of binding, which allowed normalization of binding and receptor concentrations according to protein content. Mean binding curves normalized to $200 \mu \mathrm{g}$ /assay tube of healthy control subjects and well-controlled GD did not differ significantly but were lower than those from wellcontrolled ODM women (Fig. 1 a,b). Separate calculation of the mean binding curves for the diet-treated and the insulin-treated groups disclosed pronounced differences, even with well-controlled GD (Fig. 2a,b).

The measured binding curves (cpm vs insulin concentrations) were adequately fitted by a single-site, non-cooperative binding model. Adding a second binding site to the model did not significantly improve the quality of the fit as was assessed by three different criteria (data not shown) (cf. Methods, Model selection). Therefore, the binding data were analysed by the one-site, non-cooperative binding model as a minimum model adequately fitting the data.

Maximum specific binding, as measured at $1.65 \mathrm{pmol} / 1$ unlabelled insulin, was unchanged in the total collective of GD, but was decreased by $30 \%$ in the diet-treated group and increased by $90 \%$ in the insulin-treated group $(p<0.05)$, respectively, as compared to the control subjects (Table 4). Due to variation in the data, there were no significant differences between the diet-treated group and the control subjects. However, maximum binding differed significantly between the two groups of GD $(p<0.05)$. Interestingly, non-specific binding was $35 \%$ higher $(p<0.05)$ in IGD than in the control subjects. In the ODM group maximum specific binding was higher than in the healthy control subjects $(p<0.05)$ but was similar to IGD (Table 4).

The observed differences in maximum binding were due only to different receptor concentrations whereas the affinity values were virtually the same in all groups (Table 4). Like maximum binding values, the receptor concentrations did not differ between the control group and the group of well-controlled GD unless treatment was considered. The diet-treated group had only $40 \%$ $(p<0.05)$ as many and the insulin-treated group more than twice as many receptors per $m g$ protein compared to the control subjects. In trophoblast membranes of ODM more $(p<0.01)$ receptors were present than in the control subjects.

Receptor concentrations were expressed per membrane protein content and also normalized to the activities of enzyme markers for syncytiotrophoblast, 5'-nucleotidase and alkaline phosphatase (Table 4). The results did not change qualitatively, but two aspects must be noted. First, the variation of the data within the groups as expressed by the relative standard deviations became smaller and, secondly, statistical significance $(p<0.05)$ can be attached to the different receptor concentrations in the in- 

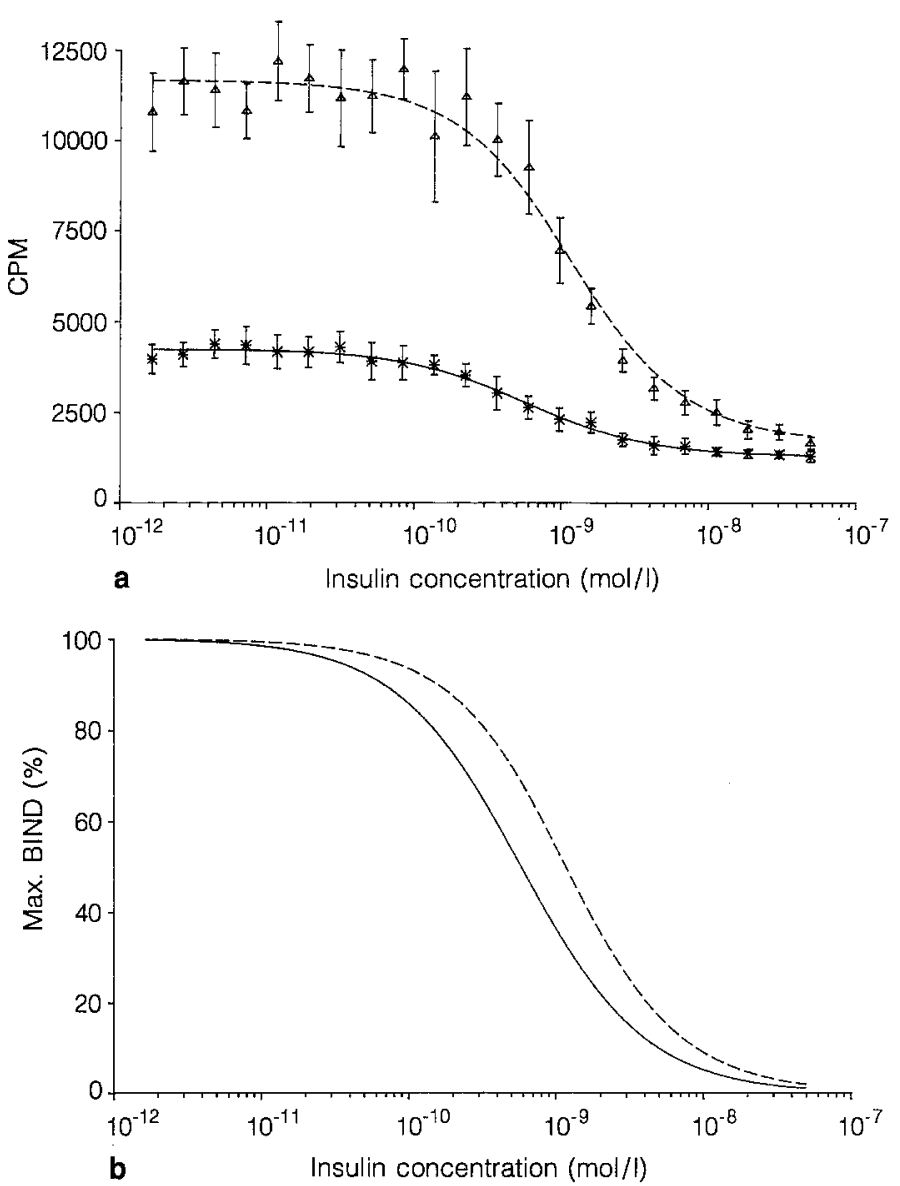

Fig. 2a,b. Competition experiments with ${ }^{125} \mathrm{I}$-insulin and unlabelled insulin on trophoblast membranes from placentae of gestational diabetic women who were treated either with diet $(-*)(n=4)$ or insulin $(\Delta---\Delta)(n=7)$. The lines represent the best fit of the data by the non-linear regression procedure. a Mean binding curve. Individual binding curves normalized for $200 \mu \mathrm{g}$ protein per assay tube, and the mean $( \pm S D)$ cpm value calculated for each concentration of unlabelled insulin. b Competition profile

sulin-treated group and control subjects if results are expressed per activity of alkaline phosphatase. Moreover, the amount of insulin receptors per total placenta was calculated from the receptor concentrations per $g$ membrane protein, from the protein concentration per g placenta, and from total placental weight. It differed between the GD groups $(p<0.05)$ (Table 4$)$.

The concentrations of receptor-insulin complex, which were calculated from the affinity and number of receptors obtained in vitro at $4{ }^{\circ} \mathrm{C}$ and from the ambient insulin concentrations in vivo, tended to be lower in the diet-treated group but large variations in the data precluded significance. However, due to the higher insulin levels, the complex concentrations were higher in IGD $(p<0.001)$ and in ODM $(p<0.01)$ than in the control subjects and in DGD (Table 4).

Maximum insulin binding $(24.3 \pm 6.7 \%)(p<0.001)$ and the concentrations of receptors $\left(6.58 \pm 1.35 .10^{-10}\right.$ $\mathrm{mol} / \mathrm{g}$ protein $)(p<0.01)$ and receptor-insulin complex $\left(10.6 \pm 3.3 .10^{-11} \mathrm{~mol} / \mathrm{g}\right.$ protein $)(p<0.001)$ were higher in women with White B diabetes $(n=6)$ than in the control subjects. The concentrations of receptor per g protein and receptor-insulin complex were also higher $(p<0.05)$ than in IGD. Maximum insulin binding $(11.1 \pm 6.0 \%)$ as well as the concentration of insulin receptors $\left(3.54 \pm 3.66 .10^{-10}\right.$ $\mathrm{mol} / \mathrm{g}$ protein) were clearly lower $(p<0.01)$ in the group White C + CR $(n=4)$ as compared to White B. In the group White $\mathrm{D}+\mathrm{DR}(n=8)$ both parameters were virtually unchanged compared to White $\mathrm{C}+\mathrm{CR}$ but still higher $(p<0.01)$ than in the control group. The affinity constants did not vary between the groups (data not shown).

Splitting the total ODM collective into subgroups comprising women without (White $\mathrm{B}+\mathrm{C}+\mathrm{D} ; n=9$ ) or with (White CR + DR; $n=9$ ) background retinopathy did not disclose any differences (data not shown).

No linear correlations were found between maternal serum insulin levels and concentrations of receptors, regardless of whether they were normalized to membrane protein (GD: $r=0.158$; ODM: $r=0.112$ ), to 5'-nucleotidase (GD: $r=0.126$; ODM: $r=0.113$ ) or to alkaline phosphatase (GD: $r=0.114$; ODM: $r=0.146$ ) activity.

If the total group of well-controlled GD was arbitrarily split into two subgroups according to the cord serum insulin (CSI) level (a parameter reflecting control of maternal diabetes) with a cut-off value of $8 \mu \mathrm{IU} / \mathrm{ml}$, only a tendency towards lower binding with increasing CSI levels, but no statistically significant differences were seen except in the degree of receptor occupancy and non-specific binding (data not shown). Also if the ODM group was split into three subgroups with CSI levels $<15 \mu \mathrm{U} / \mathrm{ml}$ $(n=5), 15<\mathrm{CSI}<30 \mu \mathrm{U} / \mathrm{ml}(n=7)$ and $\mathrm{CSI}>30 \mu \mathrm{U} / \mathrm{ml}$ $(n=6)$, respectively, no influence on binding parameters of CSI values below $30 \mu \mathrm{U} / \mathrm{ml}$ was detected. However, women with CSI exceeding $40 \mu \mathrm{U} / \mathrm{ml}$ exhibited lower binding $(14.5 \pm 10.8 \%$ compared to $20.6 \pm 10.9 \%)$ $(p<0.05)$ which was due to fewer $\left(2.68 \pm 1.75 .10^{-13} \mathrm{com}-\right.$ pared to $5.73 \pm 3.21 .10^{-13} \mathrm{~mol} / \mathrm{U}$ alkaline phosphatase) $(p<0.05)$ insulin receptors (Fig. $3 \mathrm{a}, \mathrm{b})$.

Post mortem degradation of glycogen is well known [44] and was also seen in the present study. Glycogen contents in pieces of placental tissue obtained at 5-min intervals beginning at a defined time point after delivery (between 5 and $18 \mathrm{~min}$ ) gradually decreased and showed biphasic kinetics. The kinetics of glycogen degradation were similar in all ODM groups, in GD and in the control subjects (data not shown). The glycogen content of the placentae at the time of delivery was extrapolated from the initial slope of the time dependence of glycogen loss.

In DGD both the maternal-to-cord serum glucose ratio $(p<0.001)$ and the placental glycogen content $(p<0.05)$ were reduced to about $80 \%$ of that of the control subjects. In IGD, the placental glycogen content was unchanged compared to the control subjects, despite a $40 \%$ increase $(p<0.001)$ of the maternal-to-cord serum glucose ratio (Table 5). The maternal-to-cord serum glucose ratio was higher in ODM than in the healthy control subjects $(p<0.05)$. The individual subgroups of ODM also showed higher ratios but, due to the small number of patients, statistical significance was reached only in the White $\mathrm{C}+\mathrm{CR}$ subgroup ( $p<0.05$ vs control) (Table 5). The placentae from ODM contained more glycogen $(p<0.05)$ than those from healthy control subjects. The subgroup White $\mathrm{C}+\mathrm{CR}$, which showed a markedly higher maternal-to- 

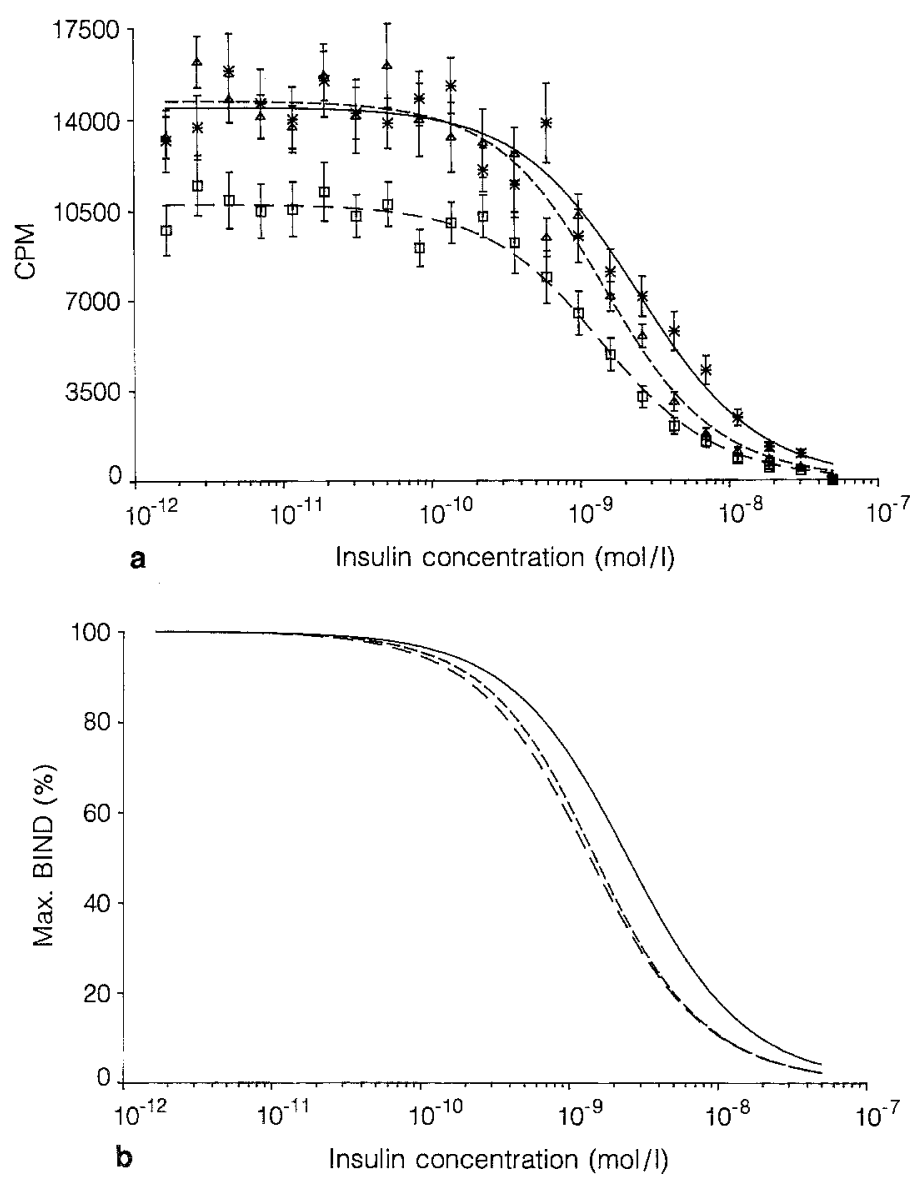

Fig. 3a,b. Competition experiments with ${ }^{125} \mathrm{I}$-insulin and unlabelled insulin on trophoblast membranes from placentae of 18 women with overt diabetes mellitus. The total collective was split according to cord serum insulin levels $<15 \mu \mathrm{U} / \mathrm{ml} \quad(*-*) \quad(n=5)$, between $15 \mu \mathrm{U} / \mathrm{ml}$ and $30 \mu \mathrm{U} / \mathrm{ml}(\Delta--\Delta)(n=7)$ and $<30 \mu \mathrm{U} / \mathrm{ml}(\square-\cdots \square)$ $(n=6)$. a Mean binding curve. Individual binding curves were normalized for $200 \mu \mathrm{g}$ protein per assay tube, and the mean $( \pm S D) \mathrm{cpm}$ value was calculated for each concentration of unlabelled insulin. b Competition profile

fetal glucose ratio and a higher placental glycogen content than the subgroups White B and White D+DR $(p<0.05)$, was an exception (Table 5). The ratio of maternal-to-cord serum glucose ratio and the placental glycogen content were virtually identical in White $\mathrm{B}+\mathrm{C}+\mathrm{D}$ and White $\mathrm{CR}+\mathrm{DR}$ patients.

\section{Discussion}

The binding of insulin to plasma membranes of placentae from metabolically healthy and well-controlled gestational and overt diabetic women was comprehensively investigated.

The question of whether and how insulin binding to the placenta is altered under diabetic conditions of the mother is important in view of the location of insulin receptors on the microvillous membrane of the syncytiotrophoblast $[8,9]$. Insulin receptors are thus in intimate contact with ambient insulin and glucose levels in the maternal circulation and may play a regulatory role and provide a link between maternal metabolic factors and the biological effects of insulin on placental function.

Despite the location of the placental insulin receptors on the microvillous membrane of the syncytiotrophoblast, we decided to prepare an overall trophoblast plasma membrane fraction. The low yield of a typical microvillous brush border membrane preparation would not have permitted measurement of insulin binding at 22 different concentrations of displacing unlabelled insulin. The preparation used in this study permitted up to nine parallel incubations at low insulin concentrations and inclusion of a total of 156 tubes per assay. This minimized the propagation of experimental errors into relevant constants, receptor affinity and receptor concentration. The characterization of the membrane preparations in the present study suggests a high enrichment of brush border syncytiotrophoblast membranes with low contamination of intracellular membranes. The very low insulin degrading activity of the membranes indicated that they were largely devoid of intracellular cytoplasmic contaminations [45]. This is at variance with a study in which insulin was degraded by about $14 \%$ during a 1 -h incubation at $24^{\circ} \mathrm{C}$ [12]. However, the present binding studies were carried out at $4{ }^{\circ} \mathrm{C}$, which may have inhibited any remaining insulin-degrading enzymes and explain why only one binding site for insulin was found [46]. Analysis of equilibrium binding of insulin to solubilized insulin receptors from human placentae under various experimental conditions with particular regard to cooperativity effects, also provided evidence of a single class of non-interacting binding sites [47].

Insulin receptor concentrations were expressed per membrane protein and also per unit enzyme activity of 5 'nucleotidase and alkaline phosphatase, which are both localized on the microvillous membrane of the syncytiotrophoblast $[48,49]$. This should have reduced any influences of varying degrees of purity in the membrane preparations and of possible differences in surface areas of syncytiotrophoblast membrane per unit tissue weight in the three groups on the results. Such a normalization is particularly important in placentae from ODM women who have an increased density of microvilli compared to those from normal healthy women [50].

The greater number of receptors in IGD and in ODM might indicate that insulin treatment is involved. Since the placental membranes were prepared and washed in large volumes of buffer, any membrane-bound insulin should have dissociated from the membrane receptor thus ruling out any influence of exogenously injected insulin on the methodology of receptor measurements. The body mass indexes, which may affect receptor concentration, were comparable in all groups. The average duration of gestation was about 2 weeks shorter in ODM than in healthy women but we regard it unlikely that the degree of surface expression of insulin receptors on the trophoblast membranes, and hence insulin binding, drops drastically between weeks 38 and 40 of gestation. Therefore, we conclude that trophoblast plasma membranes from DGD express fewer membrane insulin receptors than those from healthy control subjects, and that placentae from IGD express more insulin receptors on the trophoblast plasma membrane than those from DGD. Whether the 
Table 4. Characteristic parameters for insulin binding to placental membranes from 12 metabolically normal women (control subjects), 11 women with well-controlled gestational diabetes (GD) who were treated either with diet alone (DGD) or with diet plus insulin (IGD) and from 18 women with well-controlled overt diabetes mellitus (ODM) of different White classes

\begin{tabular}{|c|c|c|c|c|c|}
\hline & $\begin{array}{l}\text { Control subjects } \\
n=12\end{array}$ & $\begin{array}{l}\text { DGD } \\
n=4\end{array}$ & $\begin{array}{l}\text { IGD } \\
n=7\end{array}$ & $\begin{array}{l}\text { GD } \\
n=11\end{array}$ & $\begin{array}{l}\text { ODM } \\
n=18\end{array}$ \\
\hline Max bdg & $8.7 \pm 2.5$ & $6.2 \pm 2.2$ & $16.4 \pm 10.2^{\mathrm{a}, \mathrm{d}}$ & $12.8 \pm 9.2$ & $18.5 \pm 10.6^{\mathrm{a}}$ \\
\hline $\mathrm{K} \cdot 10^{9}$ & $1.94 \pm 1.54$ & $1.76 \pm 0.60$ & $1.77 \pm 1.19$ & $1.69 \pm 0.97$ & $1.97 \pm 2.12$ \\
\hline $\mathrm{R} /$ plac $\cdot 10^{-10}$ & $1.94 \pm 1.65$ & $0.83 \pm 0.91$ & $3.46 \pm 3.36^{\mathrm{d}}$ & $2.71 \pm 2.73$ & $6.53 \pm 4.39$ \\
\hline $\mathrm{R} /$ prot $\cdot 10^{-10}$ & $\begin{array}{r}1.44 \pm 0.91 \\
( \pm 63 \%)\end{array}$ & $\begin{array}{r}0.63 \pm 0.38^{\mathrm{a}} \\
( \pm 44 \%)\end{array}$ & $\begin{array}{r}3.06 \pm 2.76^{\mathrm{d}} \\
( \pm 90 \%)\end{array}$ & $\begin{array}{l}2.17 \pm 2.47 \\
( \pm 114 \%)\end{array}$ & $\begin{array}{r}4.59 \pm 3.07^{\mathrm{b}, \mathrm{f}} \\
( \pm 67 \%)\end{array}$ \\
\hline $\mathrm{R} / \mathrm{AP} \cdot 10^{-13}$ & $\begin{array}{r}1.72 \pm 0.93 \\
( \pm 54 \%)\end{array}$ & $\begin{array}{r}0.72 \pm 0.25^{\mathrm{a}} \\
( \pm 35 \%)\end{array}$ & $\begin{array}{r}3.88 \pm 3.23^{\mathrm{a}, \mathrm{d}} \\
( \pm 83 \%)\end{array}$ & $\begin{array}{r}2.44 \pm 2.73 \\
( \pm 83 \%)\end{array}$ & $\begin{array}{r}4.68 \pm 3.17^{\mathrm{a}} \\
( \pm 68 \%)\end{array}$ \\
\hline NSB & $1208 \pm 366$ & $1284 \pm 351$ & $1663 \pm 602^{a}$ & $1517 \pm 529$ & $1659 \pm 556^{\mathrm{a}}$ \\
\hline Compl $\cdot 10^{-11}$ & $1.41 \pm 0.55$ & $0.74 \pm 0.63$ & $4.40 \pm 2.65^{\mathrm{c} . \mathrm{e}}$ & $3.03 \pm 2.72$ & $5.35 \pm 4.66^{\mathrm{c}, \mathrm{g}}$ \\
\hline
\end{tabular}

Max bdg, maximum specific binding (\%); K, affinity constant (1/mol); R/plac, amount of insulin receptors per total placenta (mol $/ \mathrm{g}$ placenta); R/prot, R/5'-ND and R/AP, concentration of insulin receptors normalized to membrane protein (mol/g protein) and activities of 5'-nucleotidase $(\mathrm{mol} / \mathrm{U})$ and alkaline phosphatase $(\mathrm{mol} / \mathrm{U})$, respectively; NSB: non-specific binding (cpm) normalized to $200 \mu \mathrm{g}$ protein/assay tube and to $70,000 \mathrm{cpm}$ total radioactivity; Compl, concentration of insulin-receptor complex (mol/g protein); Occupancy, $\%$ of receptors occupied with ligand.

${ }^{\mathrm{a}} p<0.05 ;{ }^{\mathrm{b}} p<0.01 ;{ }^{\mathrm{c}} p<0.001$ vs control; ${ }^{\mathrm{d}} p<0.05 ;{ }^{\mathrm{e}} p<0.001$ vs DGD; ${ }^{\mathrm{f}} p<0.05 ;{ }^{\mathrm{g}} p<0.01$ vs IGD. Mean $\pm \mathrm{SD}$ ( \pm relative SD)

glycaemic control $\left(\mathrm{HbA}_{1 \mathrm{c}}\right.$ values $\left.>7 \%\right)$ expressed more surface insulin receptors, resulting in approximately $20 \%$ higher insulin binding, than well-controlled ODM or healthy control subjects [16]. The increase in insulin binding was due to higher receptor numbers without any significant changes of the affinities. No changes in the molecular characteristics of the receptors in the diabetic patients have been found. On the basis of $\mathrm{HbA}_{1 \mathrm{c}}$ values and the parameters of carbohydrate metabolism we regard the ODM patients in the present study as well-controlled. Moreover, insulin in the cord serum, which is also an indicator of glycaemic control, had no significant effect on the receptor concentration. Therefore, the observed differences in receptor concentrations cannot be due to differences in glycaemic control in GD.

Hyperinsulinaemia down-regulates insulin receptors. However, the patients in the present study did not show a significant hyperinsulinaemia. The presence of anti-insulin antibodies could have interfered with the insulin assay, but their concentrations did not significantly differ between the groups. Therefore, we infer that the measured insulin levels reflect the true concentrations in vivo. Interestingly, there was no correlation between maternal serum insulin levels and placental receptor concentrations in any of the groups. This may suggest that the amount of insulin receptors on the brush border membrane of the syncytiotrophoblast is not regulated by maternal insulin, or that the maternal insulin levels measured in the week preceding delivery do not reflect those during the hours preceding delivery. Receptor internalization, degradation and recycling are necessary for down-regulation of receptor concentrations by persistently high hormone levels. Since trophoblast insulin receptors do not internalize [8] we favour the hypothesis that the expression of placental insulin receptors is insen- 
sitive to concentrations of circulating maternal insulin. This is also supported by the reduced receptor concentrations despite normal fasting insulin levels in DGD.

Corticosteroids induce the expression of insulin receptor genes [52], the placenta contains receptors for corticosteroids [53] and cortisol levels are increased in ODM [54]. Therefore one could speculate that under the conditions of therapy at our institution endocrine or metabolic parameters are altered differently compared to studies reporting unchanged binding. Plasma cortisol may be a candidate for such a parameter, but has not been measured.

At present we have no explanation for the altered receptor concentrations under the various diabetic conditions. Placental insulin receptors may be regulated autonomously by the placenta or by other factors such as protein kinase $C$ [55]. The dynamics of the trophoblast plasma membrane may also be altered by the diabetic conditions. Although still controversial, modification of the membrane lipid environment may affect insulin receptor function $[7,56]$.

The present study was the first to describe insulin binding to placental membranes in a well-described, and homogenous group of GD, excluding patients with overt diabetes. One similar study reported a reduced number of insulin receptors in a non-obese group of diet-treated patients with unaltered binding affinities compared to a control collective, but provided no information on the quality of glycaemic control [12]. Our results on ODM patients are in contrast to recent reports showing unchanged insulin binding to isolated membranes [16] and intact placental villi [17] of ODM women who were well-controlled on the basis of $\mathrm{HbA}_{1}$ or $\mathrm{HbA}_{1 \mathrm{c}}$ values, respectively. Other earlier studies compared healthy control subjects with ODM patients of different severity and varying or unknown glycaemic control [13-16]. They found either a significant decrease of the receptor concentration in placentae of Type 1 diabetic mothers [13] or no differences in insulin binding to placental membranes $[14,15]$.

The physiological significance of the observed alteration of the number of insulin receptors is unclear because no insulin effects on placental physiology or metabolism have been established so far. The synthesis of glycogen is the only metabolic process in the placenta which has often been suggested to be insulin-dependent, mainly because maternal diabetes is associated with an elevated placental glycogen content. Placentae of IGD contain more glycogen if expressed as g per total placentae, whereas glycogen levels expressed in mg DNA or g placental tissue are similar to those in non-diabetic subjects $[18,20]$. The present study suggests an even more complicated picture when the mode of treatment is considered. Glycogen per $g$ tissue was decreased in patients treated with diet only, but it was unchanged in patients receiving insulin.

Some studies found effects of insulin on placental glycogen levels, other investigators failed to demonstrate such effects [57-59]. It was also suggested that the synthesis of placental glycogen is driven by hyperglycaemia alone [60]. Therefore, the maternal-to-fetal glucose gradient was also measured as one of the factors which might affect placental glycogen [61]. Very recently we were unable to demonstrate effects of physiological and patho- logical concentrations of insulin and glucose on the glycogen content in isolated and cultured trophoblast cells from human term placenta [62]. The lower maternal-tofetal glucose ratio in DGD could contribute to the lower amount of placental glycogen in this group. The steeper gradient in IGD and in ODM might reflect increased placental maternal-to-fetal glucose transfer as compared to healthy women. Studies on streptozotocin-induced diabetic rats have recently produced similar results [63]. Placental glucose transfer from the mother to the fetus is currently not known to be regulated by insulin. Thus, by inference from the enhanced maternal-to-fetal glucose ratio in IGD, the placenta should be supplied with a sufficient amount of glucose for storage as glycogen. Placental glucose transfer in rats is bidirectional and includes a backflux from the fetal to the placental compartment [64], which is also increased in rats with experimental diabetes [63]. Similar studies are lacking for humans.

In summary, the present investigation demonstrated that insulin binding to placental trophoblast plasma membranes in vitro is altered in well-controlled GD and in women with well-controlled ODM. Moreover, within $\mathrm{GD}$, insulin binding differed between women treated with diet only and those receiving insulin. The binding differences are due solely to altered receptor concentrations on the trophoblast plasma membranes, whereas receptor affinities are similar in all groups. Insulin binding did not correlate with maternal serum insulin levels and did not depend on cord serum insulin levels below $30 \mu \mathrm{U} / \mathrm{ml}$. Placentae from gestational diabetic women treated with diet contained less glycogen (if expressed per g placental weight) than placentae from healthy control subjects and gestational diabetic patients treated with insulin, whose glycogen contents were virtually the same. In overtly diabetic women the elevated placental glycogen content was paralleled by a higher maternal-to-fetal glucose ratio.

We suggest that studies on gestational diabetes should consider the mode of treatment as well as the degree of glycaemic control as factors that may influence metabolic parameters. We further suggest that the expression of more insulin receptors on the trophoblast plasma membranes is characteristic of overt diabetes mellitus and of the severe form of gestational diabetes, requiring insulin treatment to achieve glucose homeostasis.

Acknowledgements. The authors are greatly indebted to Dr. K. Tamussino for helpful criticism and editorial support. This work was supported in part by grant $P 6266 \mathrm{M}$ of the Fonds zur Foerderung der wissenschaftlichen Forschung in Oesterreich and by a grant of the Styrian regional government. Parts of this work were presented at the $2^{\text {nd }}$ meeting of the European Placenta Group in conjunction with the Rochester Trophoblast conference, Rolduc, The Netherlands, 1986, and at the $13^{\text {th }}$ International Diabetes Federation Congress, Sydney, Australia, 1988.

\section{References}

1. Weiss PAM (1988) Gestational diabetes: a survey and the Graz approach to diagnosis and therapy. In: Weiss PAM, Coustan DR (eds) Gestational diabetes. Springer, Wien New York, pp 1-55

2. Coustan DR, Lewis SB (1978) Insulin therapy for gestational diabetes. Obstet Gynecol 51:306-310 
3. Freinkel N (1980) The Banting Lecture 1980: of pregnancy and progeny. Diabetes 29: 1023-1035

4. Oats JN, Beischer NA, Grant PT (1988) The emergence of diabetes and impaired glucose tolerance in women who had gestational diabetes. In: Weiss PAM, Coustan DR (eds) Gestational diabetes. Springer, Wien New York, pp 199-207

5. Freinkel N, Metzger BE, Phelps RL et al. (1985) Gestational diabetes mellitus. Heterogeneity of maternal age, weight, insulin secretion, HLA antigens and islet cell antibodies and the impact of maternal metabolism on pancreatic B-cell and somatic development in the offspring. Diabetes 34 [Suppl 2]: 1-7

6. Kuihl C, Andersen O (1988) Pathophysiological background for gestational diabetes. In: Weiss PAM, Coustan DR (eds) Gestational diabetes. Springer, Wien New York, pp 67-71

7. Desoye G, Weiss PAM (1987) Influence of the lipid environment on insulin binding to placental membranes from normal and diabetic mothers. Trophoblast Res 2: 29-43

8. Nelson DM, Smith RM, Jarett L (1978) Non-uniform distribution and grouping of insulin receptors on the surface of human placental syncytial trophoblast. Diabetes 27: 530-538

9. Whitsett JA, Lessard JL (1978) Characteristics of the microvillous brush border of human placenta: Insulin receptor localization in brush border membranes. Endocrinology 103: 1458-1468

10. Desoye G (1988) The human placenta in gestational diabetes. In: Weiss PAM, Coustan DR (eds) Gestational diabetes. Springer, Wien New York, pp 72-86

11. Salafia CM (1988) The fetal, placental, and neonatal pathology associated with maternal diabetes mellitus. In: Reece EA, Coustan DR (eds) Diabetes mellitus in pregnancy, principles and practice. Churchill Livingstone, New York, pp 143-181

12. Duran-Garcia S, Gomez Nieto J, Maranon Cabello A (1979) Effect of gestational diabetes on insulin receptors in human placenta. Diabetologia 16:87-91

13. Harrison LC, Billington T, Clark S, Nichols R, East I, Martin FIR (1977) Decreased binding of insulin by receptors on placental membranes from diabetic mothers. J Clin Endocrinol Metab 44: 206-209

14. Posner BI (1974) Insulin receptors in human and animal placental tissues. Diabetes 23: 209-217

15. Whitsett JA, Srivastava LS (1979) Insulin receptors of placental brush border membranes in maternal diabetes. Pediatr Res 14: 365 (Abstract)

16. Bhaumick B, Danilkewich AD, Bala RM (1988) Altered placental insulin and insulin-like growth factor-I receptors in diabetes. Life Sci 42: 1603-1614

17. Nelson DM, Ortman-Nabi J, Curran EM (1990) Human placental insulin binding in normal and well-controlled diabetic patients. Gynecol Obstet Invest 29: 1-5

18. Gabbe SG, Demers LM, Greep RO, Villee CA (1972) Placental glycogen metabolism in diabetes mellitus. Diabetes 21: 11851191

19. Diamant YZ, Metzger BE, Freinkel N, Shafrir E (1982) Placental lipid and glycogen content in human and experimental diabetes mellitus. Am J Obstet Gynecol 145: 5-11

20. Diamant YZ, Kissilevitz R (1983) Metabolic changes in human placental tissue in diabetes mellitus. Trophoblast Res 1: 209-222

21. Diamant YZ, Kissilevitz R, Shafrir E (1984) Changes in activity of enzymes related to glycolysis, gluconeogenesis and lipogenesis in placentae from diabetic women. Placenta 5: 55-60

22. Hofmann HMH, Weiss PAM, Kainer F (1988) Insulin treatment of gestational diabetes. The basal-bolus concept. In: Weiss PAM, Coustan DR (eds) Gestational diabetes. Springer, Wien New York, pp 142-149

23. White P (1978) Classification of obstetric diabetes. Am J Obstet Gynecol 130: 228-230

24. Weiss PAM, Hofmann H (1985) Diabetes mellitus und Schwangerschaft. In: Burghardt E (Hrsg) Spezielle Gynäkologie und Geburtshilfe. Springer, Wien, S 337-427

25. Weiss PAM, Hofmann H (1984) Intensified conventional insulin therapy for the pregnant diabetic patient. Obstet Gynecol 64: 629-637
26. Weiss PAM, Hofmann H, Winter R, Pürstner P, Lichtenegger W (1984) Gestational diabetes and screening during pregnancy. Obstet Gynecol 63: 776-780

27. Hofmann HMH (1990) Maternal serum fructosamine and maternofetal glucose and insulin homeostasis in normal pregnancy. Arch Gynecol Obstet 248: 1-11

28. Snary D, Woods FR, Crumpton MJ (1976) Disruption of solid tissue for plasma membrane preparation. Anal Biochem 74: $457-465$

29. Haour F, Bertrand J (1974) Insulin receptors in the plasma membrane of human placenta. J Clin Endocrinol Metab 38: 334-337

30. Lowry OH, Rosebrough NJ, Farr AL, Randall RJ (1951) Protein measurement with the folin phenol reagent. J Biol Chem 193: $265-275$

31. Arkejsteijn CLM (1976) A kinetic method of serum 5'-nucleotidase using stabilised glutamate dehydrogenase. $\mathrm{J}$ Clin Chem Biochem 14: 155-158

32. Bowers GN Jr, McComb RB (1986) A continuous spectrophotometric method for measuring the activity of serum alkaline phosphatase. Clin Chem 12: 70-89

33. Fishman WH, Kato K, Anstiss CL, Green S (1967) Human serum beta-glucuronidase; its measurement and some of its properties. Clin Chim Acta 15: 435-447

34. Bowers GN Jr (1959) Measurement of isocitric dehydrogenase activity in body fluids. Clin Chem 5: 509-518

35. Warren L (1963) Thiobarbituric acid assay of sialic acids. Meth Enzymol 6: 463-466

36. Peters F, Pingoud VA (1982) A critical interpretation of experiments on binding of peptide hormones to specific receptors by computer modelling. Biochim Biophys Acta 714: 442-447

37. Magar ME (1972) Data analysis in biochemistry and biophysics. Academic Press, New York

38. Pang DT, Shafer JA (1984) Evidence that insulin receptor from human placenta has a high affinity for only one molecule of insulin. J Biol Chem 259: 8589-8596

39. Munson PJ, Rodbard D (1980) LIGAND: a versatile computerized approach for characterization of ligand-binding systems. Anal Biochem 107: 220-239

40. Akaike H (1974) A new look at the statistical model identification. IEEE Transact. Autom Control AC19: 716-723

41. Lipkin EW, Teller DC, Haen C de (1986) Equilibrium binding of insulin to rat white fat cells at $15^{\circ} \mathrm{C}$. J Biol Chem 260:1702-1711

42. Desoye G (1990) Measurement of non-specific binding by parallel or consecutive incubation procedures in receptor homogenates following tissue disintegrations by sonification. J Biochem Biophys Meth 21: 69-74

43. Freychet P, Roth J, Neville DM Jr (1971) Monoiodoinsulin: demonstration of its biological activity and binding to fat cells and liver membranes. Biochem Biophys Res Commun 43: $400-408$

44. Geddes IR, Rapson KB (1973) Post mortem degradation of glycogen. FEBS Lett 31:324-326

45. Duckworth WC, Kitabchi AE (1981) Insulin metabolism and degradation. Endocrine Rev 2: 210-233

46. Donner DB (1980) Regulation of insulin binding to isolated hepatocytes: correction for bound hormone fragments linearizes Scatchard plots. Proc Natl Acad Sci USA 77: 3176-3180

47. Kohanski RA, Lane MD (1983) Binding of insulin to solubilized receptor from human placenta. Evidence for a single class of noninteracting binding sites. J Biol Chem 258: 7460-7468

48. Matsubara S, Tamada T, Kurahashi K, Saito T (1987) Ultracytochemical localizations of adenosine nucleotidase activities in the human term placenta, with special reference to 5'-nucleotidase activity. Acta Histochem Cytochem 20: 409-419

49. Matsubara S, Tamada T, Saito T (1987) Ultracytochemical localizations of alkaline phosphatase and acid phosphatase activities in the human term placenta. Acta Histochem Cytochem 20:283294

50. Teasdale F, Jean-Jacques G (1986) Morphometry of the microvillous membrane of the human placenta in maternal diabetes mellitus. Placenta $7: 81-88$ 
51. Bhaumick B, Bala RM (1988) Increased auto-phosphorylation of insulin-like growth factor-I and insulin receptors in placentas of diabetic women. Life Sci 44: 1684-1696

52. Mamula PW, McDonald AR, Brunetti A et al. (1990) Regulating insulin receptor-gene expression by differentiation and hormones. Diab Care 13: 288-301

53. Coulam CB, Spelsberg TC (1983) The placenta as a target tissue for steroids. Trophoblast Res 1: 249-270

54. Hollingsworth DR (1983) Alterations of maternal metabolism in normal and diabetic pregnancies: differences in insulin-dependent, non-insulin-dependent, and gestational diabetes. Am J Obstet Gynecol 146: 417-429

55. Findlay DM, Michelangeli VP, Robinson PJ (1989) Protein kinase-C-induced down-regulation of calcitonin receptors and calcitonin-activated adenylate cyclase in T47D and BEN cells. Endocrinology 125: 2656-2663

56. Gould RJ, Ginsberg BH, Spector AA (1982) Lipid effects on the binding properties of a reconstituted receptor. J Biol Chem 257: $477-484$

57. Demers LM, Gabbe SG, Villee CA, Greep RO (1972) The effects of insulin on human placental glycogenesis. Endocrinology 91: $270-275$

58. Szabo AJ, Grimaldi RD (1970) The effect of insulin on glucose metabolism of the incubated human placenta. Am J Obstet Gynecol 106: 75-78

59. Barash V, Gutmann A, Shafrir E (1983) Mechanism of placental glycogen deposition in diabetes in the rat. Diabetologia 24: 63-68
60. Barash V, Gimmon Z, Shafrir E (1986) Placental glycogen accumulation and maternal-fetal responses in hyperglycemic nondiabetic rats. Diab Res 3: 97-101

61. Haguel S, Desmaiziers V, Challier JC (1989) Glucose uptake, utilization, and transfer by the human placenta as function of maternal glucose concentration. Pediatr Res 20: 269-273

62. Schmon B, Hartmann M, Jones CJ, Desoye G (in press) Insulin and glucose do not affect the glycogen content in isolated and cultured trophoblast cells of human term placenta. J Clin Endocrinol Metab

63. Thomas CR, Eriksson GL, Eriksson UJ (1990) Effects of maternal diabetes on placental transfer of glucose in rats. Diabetes 39: 276-282

64. Thomas CR, Eriksson GL, Kihlström I, Eriksson UJ (1988) The bidirectional flux of glucose across the placenta of normal and diabetic rats. In: Shafrir E, Renold AE (eds) Lessons from animal diabetes II. John Libbey, London, pp 423-426

Received: 16 July 1991

and in revised form: 4 September 1991

Dr. G.Desoye

Universitäts-Frauenklinik

Auenbruggerplatz 14

A-8036 Graz

Austria 